\title{
THE EFFECTIVENESS OF CONTENT BASED ON DYNAMIC INTELLECTUAL LEARNING WITH VISUAL MODALITY IN VOCATIONAL SCHOOL
}

\author{
Ketut Agustini \\ Ganesha University of Education \\ I Gede Partha Sindu \\ Ganesha University of Education \\ Kadek Angga Kusuma \\ Ganesha University of Education
}

\begin{abstract}
E-learning generally presented the same learning material because it considered the characteristics of all users to be homogeneous. In fact, every student had different characteristics in the learning process. The objectives of this study were: (1) To produce a simulation content and digital communication based on Dynamic Intellectual Learning with Visual Modality for the tenth grade at SMK Negeri 1 Seririt, (2) To find out the teacher's response and the tenth grade students at SMK Negeri 1 Seririt on Simulation Content and Digital Communication based on DIL with Visual Modality that had been generated. The method of this study was a research and development referred to the plomp model. The subjects of this study were the tenth grade of accounting program at SMK Negeri 1 Seririt in the academic year 2017/2018. There were various try out had been carried out, namely: validity testing by experts and effectiveness testing by using the Hake formula. The results showed that the simulation content and digital communication based on DIL with Visual Modality was valid and practically use: the effectiveness testing produced N-gain of 0.74 included in the effective category and the data analysis of the teacher and the students respond showed that it was categorized in the positive category. It showed that the output was valid, practical and effective to be used.
\end{abstract}

Keywords: content based, dynamic intellectual learning, modality visual

Permalink: http://dx.doi.org/10.21831/jpv.v9i1.21629

Contact Ketut Agustini

$\Theta$ Gane tutagustini@undiksha.ac.ic

Ganesha University of Education, Pegok, Jalan Raya Sesetan No.196, Sesetan, Denpasar Selatan, Pedungan, Denpasar Sel., Kota Denpasar, Bali 80223, Indonesia 


\section{INTRODUCTION}

SMK Negeri 1 Seririt is a Vocational High School (Sekolah Menengah Kejuruan/ SMK) located in Lokapaksa Village, Seririt District, Buleleng Regency. SMK Negeri 1 Seririt is an educational institution as a professional generation developer in various departments, namely Cullinary/Restaurant, Hospitality Accommodation, Boutique Clothing and Accounting. One of the subjects found in the accounting department is Simulation and Digital Communication.

Simulation and Digital Communication subjects become the basis for the use of computers and other ICT equipment to support the mastery of vocational productive subjects. Teachers and students must relate the use of ICT tools with subjects in the areas of expertise, expertise programs, and skill competencies they learned while in vocational high school.

SMK N 1 Seririt has facilities that support the learning process such as LCD, Computer laboratory and Wifi. However, the supporting facilities have not been used properly, so the learning process does not give a different impression for students. Based on the results of interviews with teachers of the Simulation and Digital Communication subject at SMK Negeri 1 Seririt, in the learning process the teacher uses the lecture method in which, the lecture method is less flexible in accommodating the development of competency material because educators must intensively adjust the subject matter with the development of new technologies one of which is e-learning.

Some students repeatedly read the material provided but unable to understand the material being read. The tendency of students to understand the material that only uses material will affect the absorption of students so that if students have the characteristics of laziness to read, then the task for a teacher is to replace the learning media used in the learning process. Therefore it is deemed necessary to make learning media related to Digital Simulation and Communication subjects adjust to the characteristics of students, so that students can learn independently and understand the learning material well.

Questionnaires distribution was conducted to students showed that students sometimes get bored with the learning media used by the teacher. Learners wanted teachers to use varied learning media, so that students could understand the material provided by the teacher. Learners wanted the learning media that is made not only in the form of text, but students have video and picture features so students learn more and are not bored with reading material.

From those problems it can be concluded that the learning media used by the teacher has not been able to overcome the existing problems. The results obtained from the teacher who teaches the Digital Simulation and Communication subject agree with the development of Digital Simulation and Communication content that is packaged in e-learning to suit the characteristics of students, namely visual modality. As many as $81.67 \%$ of all respondents agreed to use Digital Simulation and Communication content with visual modality that was packaged in e-learning.

E-leaning is an internet-based learning media to help teacher interaction with students in the teaching and learning process. Students can learn or review at any time and can be done anywhere. The increasing use of e-learning as a learning media impact many applications are made that support web-based learning media, namely LMS (Learning Management System). LMS is software that is used to create webbased online lecture materials and manage learning activities and results (Hanum, 2013). The developed LMS makes many different features appear in the learning process, especially in the problem of learning content. This then triggered the establishment of a new standard which was then agreed to become an international standard known as Sharable Content Object Reference Model (SCORM).

SCORM (Sharable Content Object Reference Model) was an e-Learning standard developed by $A D L$ (Advanced Distributed Learning) as a standard distribution of e-Learning packages that could be used to accomodate various specification $\mathrm{s}$ and standards for webbased e-Learning content. Content was defined as content or learning material. Content will give a benefit to the teachers for facilitate and provide the learning material based on the standards competency, basic competencies and indicators contained in the syllabus. The purpose was that the teachers was not mistaken in giving material to the students in teaching and learning process. Mastery of information technology greatly determines the extent of the 
content development in e-learning. Content in schools generally are not able adjusted learning with basic competencies and indicators. Therefore, there was a need for development that is able adjusted to the indicators and basic competencies which exist in the syllabus, namely by developing the content with the help of $e$ learning media.

The learning model used in this study is the Dynamic Intellectual Learning (DIL) learning model because DIL Model allowed the users to explore a learning content according to the characteristics of the students, the level of knowledge and learning styles of the students. E-learning generally presents the same learning material for each user because they assumed the characteristics of all users were homogeneous. Homogeneity was a characteristics of e-learning users who are considered the same, whereas in the reality each student has different characteristics in learning.

The advantages of e-learning that was homogeneous are (1) learners could review the instructional material being studied, (2) not wasted learning time if educators were unable to attend to teach in the class, (3) the students and the educators could conduct the discussions through the internet. E-learning deficiencies was homogeneous: (1) e-learning users was considered the same, (2) was unable to distinguish learning styles from the students, (3) the students who was not in accordance with the learning style, will be lazy to do the tasks given by the educator.

Schools in general need to have e-learning was able accommodated the differences in characteristics of the students, who could understand the students and tried provided /delivered the learning content called adaptive learning. The students now needed saw the learning content that was appropriate to their taste, level of understanding, and personal traits, so that the learning process would be more efficient if the needs of students was met. Adaptive learning provided learning material whose level of difficulty was in accordance with the user's ability and how presented the learning material in accordance with the learning style users.

Learning style is the way for everyone to absorb information through their senses. Everyone has a different tendency to absorb information. This causes the content learned is not in accordance with the characteristics of each student, so that what is obtained also becomes less optimal.

Based on previous research related to content research, several relevant research results were found, including Nurcahyono \& Permanasari (2015) entitled The Use of Learning Content for Vocational High School Students was declared effective. From the results of research that has been carried out the trend of effectiveness in the use of e-leaning learning at SMK Negeri 2 Wonosari Gunung Kidul shows that the implementation of e-leaning learning as a learning medium in SMK N 2 Wonosari Gunung Kidul is quite effective with a tendency level of $78.15 \%$ but still there $5.25 \%$ of the implementation of e-leaning learning is not effective.

Some studies also state that some of the characteristics that influence student success in learning are motivation, knowledge ability and learning style so that the elearning content developed is adaptive according to the characteristics of the students (Esichaikul, Lamnoi, \& Bechter, 2011; Sfenrianto, Hasibuan, \& Suhartanto, 2013; Surjono, 2011; Suryani \& Nasuha, 2014).

Based on the description of the above problems, the researcher intends to develop content that will be packaged in e-learning in this study entitled: "Development of Content Based on Dynamic Intellectual Learning with Visual Modality at SMK Negeri 1 Seririt".

\section{RESEARCH METHOD}

The research method is the basis for developing a product that will be produced. This study used the design development of the Plomp model. The development design of the Plomp model is one of the systematic design models that is appropriate for use in educational development research. This model consists of five steps, namely: (1) preliminary investigation, (2) design, (3) realization/construction, (4) test, evaluation, revision, and (5) implementation. However, the researchers did not carry out the implementation phase because the researchers had limited time. 
Table 1. Table Diagram of Development Phase of plomp models

\begin{tabular}{lll}
\hline No & Plomp Phase & Methods \\
\hline 1 & Preliminary & Collect the \\
& Investigation Phase & information \\
2 & Design Phase & Designing the products \\
3 & Realization Phase & Producing the products \\
4 & Test, Evaluation, & Testing the validity of \\
& and Revision Phase & product \\
\hline
\end{tabular}

\section{Techniques of Data Collection}

Qualitative and quantitative were used in order to collect the data. Techniques of data collection in this study were using interview and questionnaires methods that researcher took from the data of teacher and student.

Questionnaires method was used in the review activities of experts in the field of study, expert of media-learning design, functional testing, individual try out, small group try out, and field try out. The experts test and functional test consists of two choices, namely Appropriate and Not Appropriate. For individual try out, small group try out, field try out, and response tests consist of five choices, namely Strongly Agree (SA), Agree (A), Less Agree (LA), Disagree (D) and Strongly Disagree (SD). Table 2 is the detail of data collection.

\section{Techniques of Data Analysis}

In this development research, the data analysis aimed to answer the formulation of the problem in conclusion. The following was the data analysis technique used by researchers, including:

\section{Data analysis of content validity}

Data analysis of content validity is intended to determine the extent to which the content that has been made meets the criteria based on the expert's assessment that is appointed by using the expert validation sheet, functional testing sheet, and becomes the basis for the revision.

\section{Data analysis of teacher's and student's response}

Data analysis of teacher's and student's response is intended to find out how the teacher's and student's response to the content developed

\section{Data Analysis of Content Validity}

Content validation was tested by content experts, media-design experts, functional testing, individual testing, small group testing, field testing, analyzing teacher's and student's responses to the development of Digital Simulation and Communication content, as described below.

\section{Expert Validation Content}

This validation aimed to find out the contents contained in the learning content. The assessment results of experts were crosstabulation, for example for two assessors as in Table 3.

Table 2. Data collection

\begin{tabular}{|c|c|c|c|}
\hline No & Data type & Method & Data source \\
\hline 1 & $\begin{array}{l}\text { Information about learning } \\
\text { resource }\end{array}$ & $\begin{array}{l}\text { interview and } \\
\text { questionnaire }\end{array}$ & $\begin{array}{l}\text { Teacher of simulation and digital } \\
\text { communication subject matter }\end{array}$ \\
\hline 2 & $\begin{array}{l}\text { Information related to } \\
\text { learning problem }\end{array}$ & interview & $\begin{array}{l}\text { Tearcher of simulation and digital } \\
\text { communication subject matter. }\end{array}$ \\
\hline 3 & Learner characteristic & $\begin{array}{l}\text { interview and } \\
\text { questionnaire }\end{array}$ & $\begin{array}{l}\text { Leaner and teacher of simulation and digital } \\
\text { communication subject matter }\end{array}$ \\
\hline 4 & e-learning content validity & questionnaire & $\begin{array}{l}\text { Instructional content expert, media expert and } \\
\text { instructional design expert }\end{array}$ \\
\hline 5 & Fungsionality validity & questionnaire & PTI student \\
\hline 6 & Leaner and teacher respon & questionnaire & $\begin{array}{l}\text { Leaner and teacher of simulation and digital } \\
\text { communication subject matter }\end{array}$ \\
\hline
\end{tabular}


Table 3. Gregory Test Tabulation

\begin{tabular}{llcc}
\hline & \multicolumn{3}{c}{ Assesor 1 } \\
\cline { 3 - 4 } & & $\begin{array}{c}\text { Not } \\
\text { Appropriate }\end{array}$ & Appropriate \\
\hline Not Appropriate & (A) & (B) \\
Assesor 2 & Appropriate & (C) & (D) \\
\hline
\end{tabular}

Calculation of validity with the formula: Validity $=\frac{\mathrm{D}}{\mathrm{A}+\mathrm{B}+\mathrm{C}+\mathrm{D}}$

Note:

A : Cell that shows disagreement between the two assessors

$\mathrm{B}, \mathrm{C}$ : Cell that shows different views between assessors

D : Cell that shows valid agreement between the two assessors.

\section{Media-Design Expert Validation}

Media-design validation was carried out by learning media design experts. In this case, there was validation of the exact layout of the form of learning content writing and structuring the elaboration of the material. Assessment of the results of the learning design expert test was calculated by the Gregory formula which can be seen in table 1 .

\section{Functional Testing}

Functional testing is a method of testing emphasizing on carrying out functions and input checks and output data. Functional testing includes features contained in the system. This test was conducted to determine the validity of the system addressed to respondents outside the researcher.

\section{Individual Validation, Small Groups, Fields}

Individual validation is carried out by classes which have Simulation and Digital Communication subjects. The formula used to calculate the percentage of each subject could be seen as follows:

Percentage $=\sum \frac{\text { (Answers } \times \text { weight of each choice) }}{n \times \text { highest weight }} \times 100 \%$

Note: $\Sigma=$ total

Next, to calculate the percentage of the whole subject, the formula used:

$$
\text { Persentase }=(\mathrm{F}: \mathrm{N})
$$

Note:

$\mathrm{F}:$ the total percentage of all subjects

$\mathrm{N}$ : the total subject

\section{Gain Score Test}

Calculation of the gain score test used calculations N-gain in which Gain was increased ability of students after learning. Gain was obtained from the difference between the results of the pre-test and post-test. $\mathrm{N}$-gain was calculated by using the formula as follows:

$$
N-\text { Gain }=\frac{\text { Posttest Score }- \text { Pretest Score }}{\text { Maximum Score }- \text { Pretest Score }}
$$

\section{Teachers' and Students' Response Test}

To calculate the analysis of teacher and student response data used descriptive statistics and the conclusion was based on Mean Ideal (Mi) and ideal standard deviation (Si). Students' responses were explored by using a questionnaire with a 5 Likert scale (values from 1 to 5) which were analyzed descriptively. The class average of teachers' and students' response scores was calculated by using the formula.

$$
\bar{x}=\frac{\sum x}{N}
$$

Note:

$\bar{x} \quad$ : Class averages for teachers' and students' response scores

$\sum x$ :The total scores of teachers' and students' response

$\dot{N} \quad$ : the total number of teacher and student Whereas, to find the ideal mean (Mi) and ideal standard deviation (SDi) the following formula is used:

$M i=\frac{1}{2}$ (ideal maximum score + ideal minimum score $)$ $S i=\frac{1}{6}($ ideal maximum score - ideal minimum score $)$

\section{FINDINGS AND DISCUSSIONS}

Content created by using e-learning as a learning medium. E-learning as a place to enter content created to help students in distance to learn by using the use case diagram design which is then applied in SCORM standard elearning. SCORM (Sharable Content Object Reference Model) is a standard distribution of e-learning packages that can be used to accommodate various specifications and standards for web-based e-learning content. The research model used in this study was the Plomp model. This model has four stages, namely: 


\section{Preliminary Investigation phase}

In the analysis phase, there were: (1) analysis of the characteristics of the field of study. The purpose of Simulation and Digital Communication subject was providing an understanding of concepts and practices regarding the use of technology and information. The characteristic of Simulation and Digital Communication subject was understanding concept and practicum (2) analysis of students' characteristics. In this analysis students wanted a learning video or material in the form of images to facilitate students' understanding. (3) Analysis of learning resources. In the analysis of learning resources, teachers use Students Worksheet (LKS), searching for teaching materials on the internet and books from the library.

\section{Design Phase}

This phase was making a design that would be applied in the next phase. The design made as follows

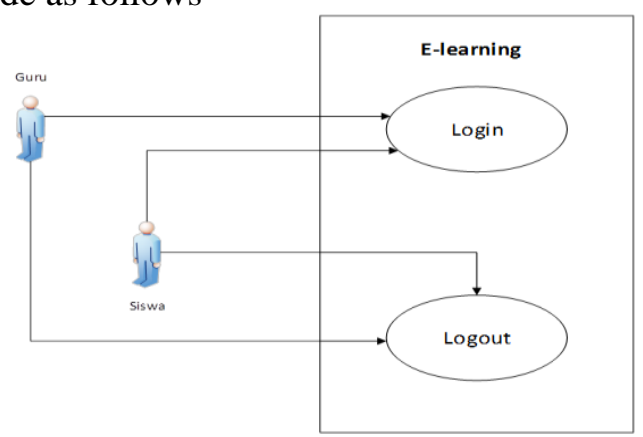

Figure 1. Use case diagram for system access

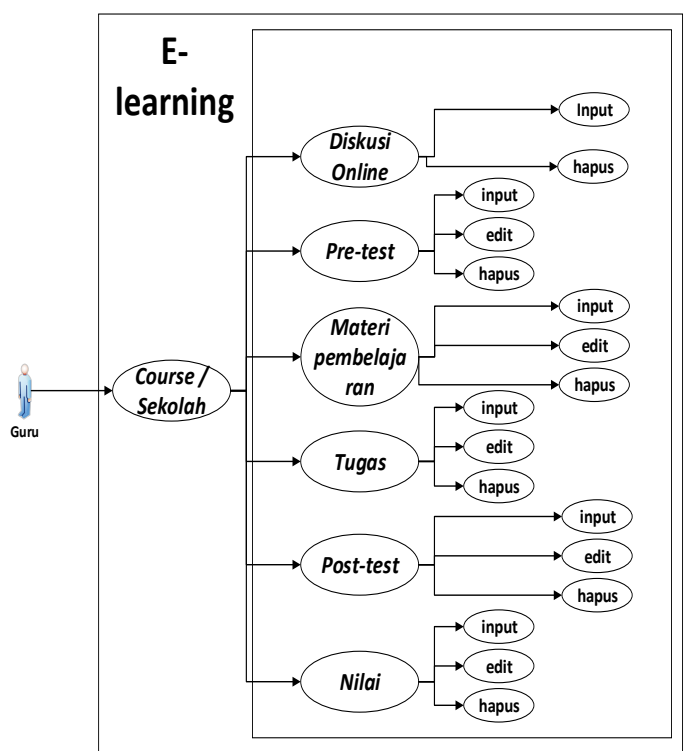

Figure 2. Use case teacher diagram

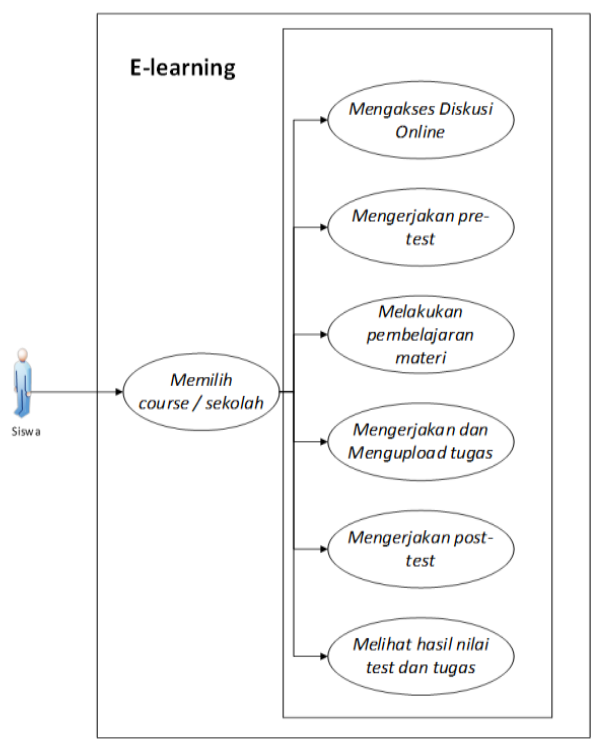

Figure 3. Use case students diagram

\section{Realization phase}

At this stage, systems are developed such as making access right to the school yard, arranging displays in each learning activity, applying Simulation and Digital Communication content to e-learning system and applying dynamic intellectual learning stages to e-learning systems. Presentation of content Digital Simulation and Communication using a scorm that was first made in the adobe captivate application before being distributed to elearning. Content that has been created in the adobe captivate application would be compressed in zip form. Product development results can be seen in Figure 4.

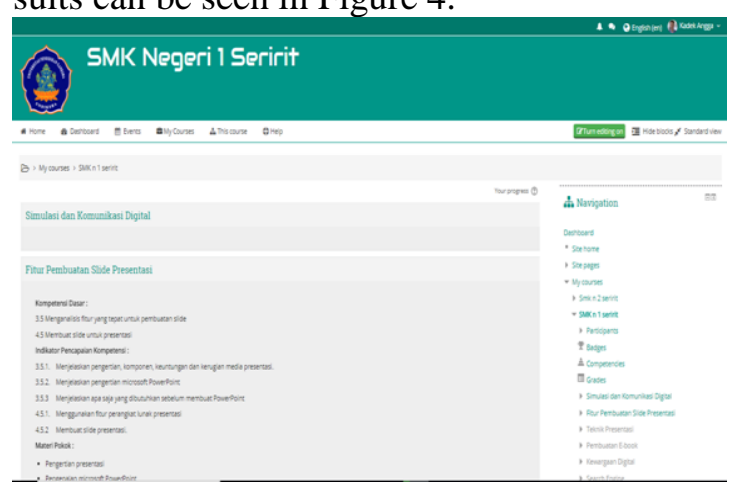

Figure 4. The results of page development for Digital Simulation and Communication content

\section{Test Phase, Evaluation and Revision}

In the test phase of e-learning content in accordance with the role and the function in the learning process to determine the extent of the 
benefits of the products developed. The test phase starts from the experts reviewed.

The result of the content expert evaluation by using Gregory test based on the questionnaire indicate that the level of achievement of the content is "Very High" and deserves to be continued. It indicates that the learning material that was implemented in e-learning content is relevant to use in learning Digital Simulation and Communication.

The results of expert evaluation of learning media by using Gregory test based on the questionnaire indicate that the level of achievement of content e-learning is declared "Very High" and deserves to be continued. This indicates that the application of intellectual learning dynamic in learning model is appropriated to use in learning.

After conducting an expert review, the next step is to conduct the functional testing of 5 respondents from Informatics Engineering student. The assessment results show that the features and processes that contained in elearning are running well and that there are no errors or non-conformity of the results of the process expected in e-learning.

The next step is to do individual test. The subjects of individual test were 3 students of $10^{\text {th }}$ grade students from accounting program. Based on the result of from Try-out questionnaire filled by each student, one student who gave very good response was (33.3), two students who gave very good responses were $(66.7 \%)$. The mean score of students is $86.67 \%$. If it converted into conversion tables that were in good category.

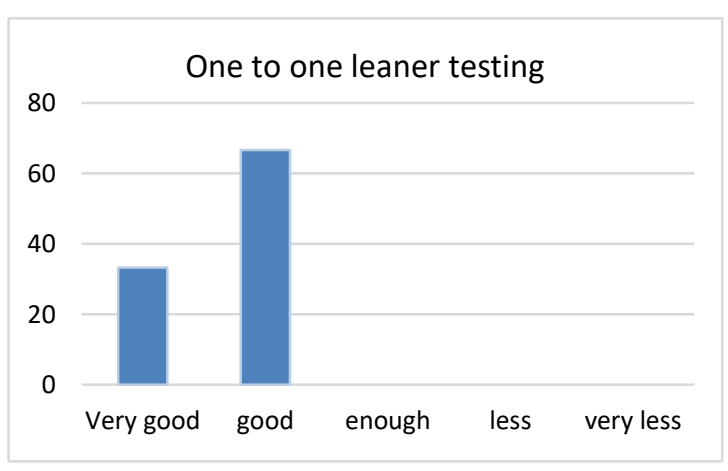

Figure 5. One to one leaner testing.

After the individual test is finished, then followed by a small group test. Test subjects of Individual test were $10^{\text {th }}$ grade students from accounting program. From the results of the small group test questionnaire filled by each students, there are two students give very good response were (20\%) and eight students give a good response were $(80 \%)$. The average ratings of ten students were $85.30 \%$. If it converted into conversion tables that were in good category.

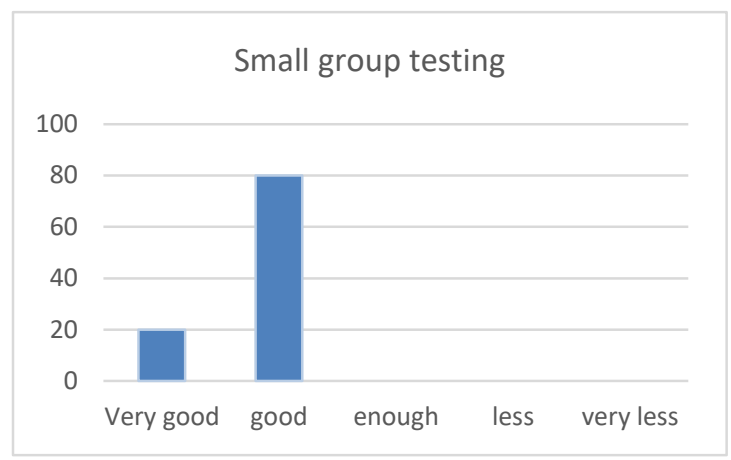

Figure 6. Small group testing

After the small group trial was completed, it continued with field tests conducted by twenty students of $10^{\text {th }}$ grade students from accounting program. From the results of the field test questionnaire obtained two the students who gave very good responses were (10\%), eighteen students who gave good responses were $(90 \%)$. The Average score of the total field test respondents were $84.25 \%$.If it converted into conversion tables in the level of achievement is included in either category.

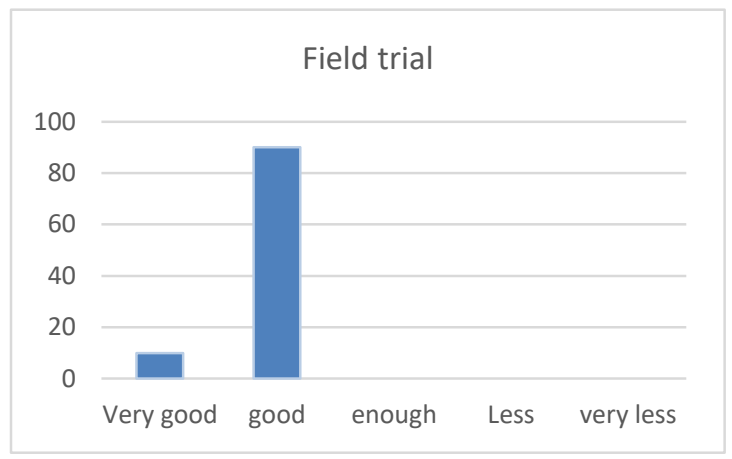

Figure 7. Field trial

After that, a gain score test that was carried out by giving the pre-test and post-test during the field test. For the N-Gain calculation formula, it is calculated by using the following formula;

$$
\begin{aligned}
N-\text { Gain } & =\frac{\text { Skor Posttest }- \text { Skor Pretest }}{\text { Skor Maksimal }- \text { Skor Pretest }} \\
& =\frac{8.4-3.9}{10-3.9} \\
& =\frac{4.5}{6.1}=0.74
\end{aligned}
$$


After the calculation was obtained, the $\mathrm{N}$ Gain value is 0.74 , so the rate of increase in the post-test results was included in the medium criteria. For categories based on N-Gain criteria can be seen in table 4 and a comparison chart of the pre-test and post-test values can be seen on the Figure 8.

Table 4. Categories based on normalized gain criteria table.

\begin{tabular}{ll}
\hline Index & Criteria \\
\hline $0.70<\mathrm{g}<1.00$ & effective \\
$0.30 \leq \mathrm{g} \leq 0.70$ & Effective enough \\
$0.00<\mathrm{g}<0.30$ & Less effective \\
\hline
\end{tabular}

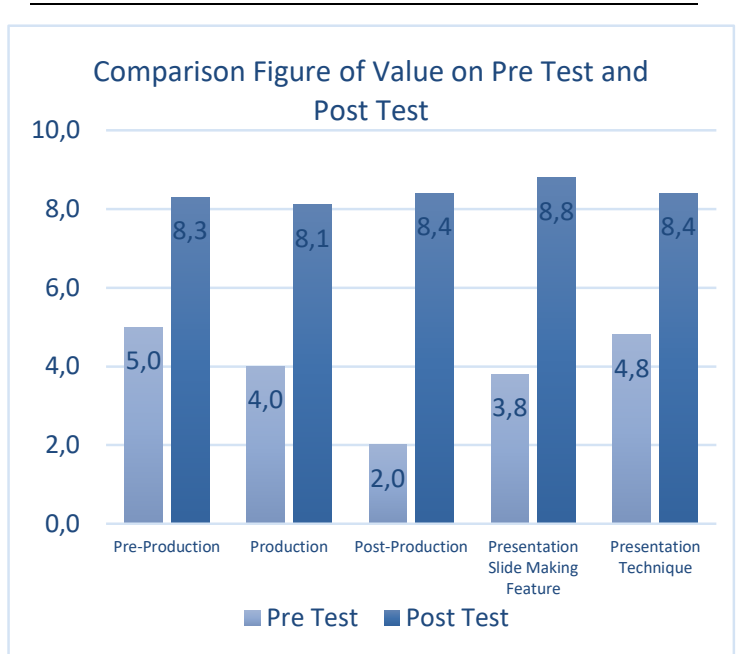

Figure 4. Comparison of pre-test and post-test scores

After that, the teacher's response was taken due to the development of Digital Simulation and Communication content which was packaged in e-learning. The teacher response test obtains an average of 45 , if it is converted into the response classification criteria table, the results are included in the very positive meaningful category, and this e-learning content was very helpful in the learning process in school and understanding students to study harder.

The next test process is carried out by taking student responses. The subject of the students' response test consisted of 20 students of Grade X Accounting who had learned to use Digital Simulation and Communication content packaged in e-learning. The results of the student response questionnaire on the development of Digital Simulation and Communication content gained an average of 65.45 , if converted into the response classification criteria table the results were included in the positive category which means that students were very enthusiastic in using the e-learning system.

Based on the results of teacher and student responses, it can be categorized to help students understand the subjects of Simulation and Digital Communication subjects and gained successfully overcome from problems that exist in the teaching and learning process which has been explained previously. From the acquisition of these responses, it indicate that the learning media can increase students' motivation to learn so that they get optimal learning outcomes. This was evidenced in the study Hernawati \& Aji (2016) which states that the results of testing and measuring e-leaning content in the database programming courses can increase student learning interest by $87 \%$ and $83 \%$ understand database programming material. While the results of testing on interest in e-leaning material content on average show a positive response. Besides that, it was also proven by Sindu \& Paramartha (2018) which stated that the average value in learning achievement of students who learned from problem-based learning content was higher than those who learned from using conventional models. Problem-based learning content plays a role in improving student learning achievement.

From the results and discussions that have been presented, assessments made by content experts, learning media experts, individual tryout, small group tryout, field tests, and the results of teacher and student responses are categorized as good and receive a positive response. This is supported by a number of student statements, namely the existence of Digital Simulation and Communication content that is packaged in e-learning is very helpful in the learning process, content that is packaged in e-learning is very useful and understand quickly in the teaching and learning process, content packed in e-learning is very helpful in the teaching and learning process. This is evidenced in the research from Zyainuri \& Marpanaji (2012) which states that the use of e-learning effectively improves students' cognitive learning outcomes.

This is evident from the results of differences in scores of increased pre-test and post-test. Besides that, it is proven in the research Tandirerung \& Hadi (2014) which states the usefulness of e-learning is very beneficial 
for teachers and students and the implementation of e-learning according to the teacher is increased while according to students is fixed. Based on these assessments, the development of Digital Simulation and Communication content based on Dynamic Intellectual Learning with Visual Modality for class $\mathrm{X}$ at SMK Negeri 1 Seririt broadly has shown success and is effectively used as a learning resource for class X students of SMK Negeri 1 Seririt.

\section{CONCLUSIONS}

Based on the results and discussion which focused on a simulation content and digital communication based on Dynamic Intellectual Learning with Visual Modality, the researcher concludes that: Fisrt, the design result and the realization of a simulation content and digital communication based on Dynamic Intellectual Learning with Visual Modality for the tenth grade at SMK Negeri 1 Seririt had been declared successful. The system design used in this research was the use case diagram which was then applied in the SCORM standard e-learning.

Second, the teacher's response to a simulation content development and digital communication based on Dynamic Intellectual Learning with Visual Modality for the tenth grade at SMK Negeri 1 Seririt, from the average obtained was 45 included in the positive category. While the students' response to the simulation content and digital communication from the average obtained is 65.45 included in the positive category. From the responds obtained, it indicates that the learning media can increase students' motivation to learn.

Based on the researcher's observation, there were several things that could be taken into consideration to be followed up. Fisrt, for other content developers in order to manage content packaged in e-learning is more user friendly or easy to use by users who are still unfamiliar with computer-based learning. In addition, it can regulate that each stage of Dynamic Intellectual Learning has features that can provide challenges in the form of games, badges or other forms so that students do not feel bored while learning by using content packed in e-learning.

Second, Product the simulation content and digital communication based on Dynamic Intellectual Learning with visual modality de- veloped has not arrived at the implementation stage. Therefore, it is necessary to conduct further studies on the effectiveness of the use of the simulation content and digital communication relating to the measurement of student learning outcomes using this simulation content and digital communication through the experimental research.

Third, product the simulation content and digital communication based on Dynamic Intellectual Learning with Visual Modality has not done the Index of Difficulties and Differential Power Index. So, it is necessary to conduct further studies on the items through experimental research.

\section{REFERENCES}

Esichaikul, V., Lamnoi, S., \& Bechter, C. (2011). Student modelling in adaptive elearning systems. Knowledge

Management and E-Learning, 3(3), 342355.

Hanum, N. S. (2013). Keefetifan e-learning sebagai media pembelajaran (studi evaluasi model pembelajaran e-learning SMK Telkom Sandhy Putra

Purwokerto). Jurnal Pendidikan Vokasi, $3(1)$. https://doi.org/10.21831/jpv.v3i1.1584

Hernawati, E., \& Aji, P. (2016). Perancangan dan penerapan konten e-learning melalui learning management system dalam meningkatkan motivasi belajar studi kasus pada mata kuliah Pemrograman Basis Data. Journal of Information Systems Engineering and Business Intelligence, 2(1), 23. https://doi.org/10.20473/jisebi.2.1.23-32

Nurcahyono, N., \& Permanasari, A. E. (2015). Pemanfaatan konten pembelajaran bagi siswa sekolah menengah kejuruan. In Seminar Nasional Sistem Informasi Indonesia (SESINDO). Surabaya: Departemen Sistem Informasi, Institut Teknologi Sepuluh Nopember.

Sfenrianto, Hasibuan, Z. A., \& Suhartanto, H. (2013). An automatic approach for identifying triple-factor in e-learning process. International Journal of Computer Theory and Engineering, 5(2), 371-376. 
https://doi.org/10.7763/IJCTE.2013.V5. 712

Sindu, I. G. P., \& Paramartha, A. A. G. Y. (2018). The effect of problem-based elearning content on the learning achievement in basic computer system course (DSK) of the student of informatics engineering education department. Jurnal Pendidikan Vokasi, 8(1), 24.

https://doi.org/10.21831/jpv.v8i1.18098

Surjono, H. D. (2011). The design of adaptive e-learning system based on student's learning styles. International Journal of Computer Science Information and

Education Technologies (IJCSIT), 2(5), 2350-2353. Retrieved from http://ijcsit.com/docs/Volume 2/vol2issue5/ijcsit20110205108.pdf
Suryani, M., \& Nasuha, A. (2014). Pengembangan personalisasi gaya belajar pada e-learning dengan menggunakan Felder Silverman learning style model untuk sekolah menengah kejuruan. In Seminar Nasional Pendidikan Teknik Informatik. Bali.

Tandirerung, V. A., \& Hadi, S. (2014). Implementasi e-learning program keahlian TKJ di SMK DIY pasca pembubaran RSBI. Jurnal Pendidikan Vokasi, 4(1). https://doi.org/10.21831/jpv.v4i1.2538

Zyainuri, Z., \& Marpanaji, E. (2012). Penerapan e-learning moodle untuk pembelajran siswa yang melaksanakan prakerin. Jurnal Pendidikan Vokasi, 2(3). https://doi.org/10.21831/jpv.v2i3.1046 